\title{
DEVELOPMENT OF SPEED-POWER ABILITIES IN YOUNG SAMBISTS
}

\author{
Abdurazzok Kurbanovich Ustoev
}

Teacher, Head of The Department of Sports Management, Termez State University, Uzbekistan

\section{ABSTRACT}

The purpose of this article was to develop and experimentally substantiate the effectiveness of the training methodology for young sambo wrestlers $10-11$ years old with a focus on the speed-strength component. The experiment was attended by 24 young sambists from the sports school of the city of Termez, Surkhandarya region. The athletes were divided into experimental and control groups. A specially organized pedagogical experiment lasted 20 weeks. The content of the training sessions of the experimental group included a large number of general developmental and special exercises aimed at the development of speed-strength abilities of athletes. We used exercises with rubber shock absorbers, weights, jumping exercises, throwing various objects, games with elements of martial arts, outdoor games and exercises that contribute to the development of the ability to quickly tension and relax muscles.

KEYWORDS:- Speed-strength training, young sambists, speed-strength orientation, dynamics of physical exercises, physical training.

\section{INTRODUCTION}

The socio-economic and political situation that has developed in the Republic of Uzbekistan currently significantly affects the traditional system of physical education of young people. In recent years, there has been a tendency to a deterioration not only in the health status of school-age children, but also in the overall level of their physical development and fitness. In our opinion, this situation can be corrected by attracting children to systematic practice of various sports, in particular, sambo wrestling.

All this requires radical changes in the methods and means of the educational-training process, a more in-depth individual approach based on a comprehensive study of the capabilities of young sambists [1]. Unfortunately, the issues of choosing a training methodology for sambo wrestlers at the initial stage are solved individually by each trainer, while mistakes are often observed in choosing the most optimal methodology. Correspondingly, this leads to shortcomings in solving the main tasks of this stage of long-term training of sambists, which in the overwhelming majority are manifested at subsequent stages, when it is difficult to fix [2, pp. 77-82].

\section{THE MAIN FINDINGS AND RESULTS}

Speed-strength training is one of the most significant components of long-term training of sambists. The success of the performance to a certain extent depends on the athlete's ability to develop maximum muscle efforts in the shortest possible time with high efficiency of technical actions fulfillment.

Analysis of scientific literature. The main 
CURRENT RESEARCH JOURNAL OF PEDAGOGICS 2(11): 157-160,

November 2021 DOI: https://doi.org/10.37547/pedagogics-crjp-02-11-30

ISSN 2767-3278

(C)2021 Master Journals

Crossref do: 81 Google

Accepted 25th November, 2021 \& Published 30 ${ }^{\text {th }}$ November, 2021

provisions of the long-term training of sambists, its stages and content, are reflected in the works of R. Piloyan (1999), V. Oshchepkov, A. Kharlampiev (1965), Ya.Koblev (1995), G. Tumanyan (1989), G. Arzyutov (1995), M. Shabeto (2000), D. Rudman (2000).

The author notes that primary school age is a period of intensive growth of speed-strength abilities, which play an important role in sambo wrestling to achieve high sports results, as well as in the harmonious physical development of children. However, the issues of developing a more rational methodology for the development of speed-power abilities of sambists at the stage of initial training were considered only partially and require further development $[3$, pp. 352356].

Relevance and research formulation. Theoretically substantiate and develop a methodology for the development of speedstrength qualities of sambists at the stage of initial training and experimentally check its effectiveness.

To achieve the goal, the following tasks were set:

1. Conduct an analysis of scientific and methodological literature on this topic.

2. To study traditional means and methods of speed-power qualities development, used in the system of sports training in different types of single combats at the stage of initial training.

3. To develop a methodology for the development of speed-strength qualities of young sambists.

4. Investigate the effectiveness of the developed methodology for the development of speed-strength qualities and determine its influence on the development of motor abilities and the effectiveness of technical readiness of young sambists of 10-11 years old [4, pp. 353-357].
Research methods: scientific methodological literature analysis, pedagogical observations, pedagogical experiment, video recording and methods of mathematical statistics.

Research results. As a result of the study, we developed a methodology for speed-strength training of young sambists, which was based on the principle of combining the means of general and special physical training, selected taking into account the age characteristics of young sambists of 10-11 years old. Unlike traditional methods of physical training of sambists, at the initial stage, the volume of speed-strength exercises, both general developmental and proper strength, was significantly increased, and outdoor games were also used.

The study was carried out on the basis of the SAMBO section of the Youth Sports School in Termez (the age of the subjects was 10-11 years; the duration of sambo training was 1.5-2 years). Initially, the selection of young sambists was carried out to form the experimental and control groups. For this purpose, to determine physical fitness, control tests were carried out with the help of specially selected test exercises, which are widely used to control the level of development of physical abilities.

During testing, we complied with all the requirements that ensure the reliability, stability and information content of proof tests. The following indicators were tested: running on $1000 \mathrm{~m}$, flexion and extension of the arms in the lying position, pulling up on the bar, hanging on bent arms (c), long jump from the spot (cm), triple jump $(\mathrm{cm})$, throwing the ball $(1 \mathrm{~kg})$ from below forward with two hands $(\mathrm{cm}), 8$ throws of the dummy (c), $30 \mathrm{~m}$ run (c), shuttle run $4 \times 10 \mathrm{~m}$ (c), performing three revolutions (forwardbackward-forward), (c), balance on one leg (c), tilting the body forward from a sitting position (cm) [5, pp. 955-958].

On the basis of the received initial data, the EG 
CURRENT RESEARCH JOURNAL OF PEDAGOGICS 2(11): 157-160,

November 2021 DOI: https://doi.org/10.37547/pedagogics-crjp-02-11-30

ISSN 2767-3278

(C)2021 Master Journals

Crossref do: 81 Google

Accepted 25th November, 2021 \& Published 30 ${ }^{\text {th }}$ November, 2021

and CG $(\mathrm{n}=30)$ the number of subjects were created, who had 15 athletes in each. The data of physical development of the studied groups at the beginning of the experiment did not differ significantly $(p>0.05)$.

Then, for the subjects of the experimental group, for seven months, we introduced an experimental methodology for the development of speed-strength abilities. The study and the control group were trained according to the traditional method [6, pp. 64-74].

The content of educational and training sessions according to the experimental program included a large number of general developmental and special exercises that affect the development and improvement of speed-strength abilities. For the development of speed-strength abilities, exercises with rubber shock absorbers, burdens, jumping exercises, throwing various objects, outdoor games and exercises that contribute to the development of the ability to quickly tension and relax muscles and games with elements of martial arts were widely used. The main methods used were: complex method; shock method; game method; method of short-term efforts; method of dynamic efforts [7, pp. 381383; 8, pp. 73-79].

As a result of retesting at the end of the experiment, the following data was obtained. Almost all indicators in control trials increased in comparison with the baseline data for each subject. Changes in both groups were statically probable for all indicators. Only one indicator in the experimental group - running at $1000 \mathrm{~m}$, which reflects general endurance, changed statistically not likely $(\mathrm{t}=1.38)$.

As for the indicators characterizing speedstrength readiness, more pronounced positive changes are observed in the athletes of the experimental group. Thus, a comparative analysis of the final results of the physical fitness study of 10-11 years old sambo wrestlers determined that the following indicators became much better in the experimental group: lifting in a sit for $1 \min (t=2.21)$.

The data obtained experimentally indicate that the proposed model of development and improvement of the studied abilities of young combatants has a positive effect on the level of speed-strength endurance and explosive strength. The analysis of the results of our research indicates that the CG and the EG differ among themselves in terms of speed-strength abilities, which is the result of using various training methods [9, pp. 1322-1329].

In the course of the experiment, it turned out that the experimental training program for young sambists of 10-11 years old, which was aimed at increasing the volume of speed-strength exercises, is more effective in comparison with the traditional training method. This is evidenced by the data we obtained, which do not contradict the studies of other authors. Along with this, the dynamics of indicators of the effectiveness of technical actions fulfillment by young athletes of the experimental and control groups (in competition conditions) was determined during the study period. This made it possible to establish that the model of development and improvement of the speed-power abilities of young sambo wrestlers, developed by us, has a positive effect on the level of technical readiness in sambo wrestling.

\section{Conclusion}

The above data indicate that the experimental program was more effective than the traditional training program that was used in the control group.

Thus, the analysis of the research results showed that speed-strength training is the most dominant in the physical training of wrestlers. The experimental methodology, focused on the accentuated improvement of speed-power 
CURRENT RESEARCH JOURNAL OF PEDAGOGICS 2(11): 157-160,

November 2021 DOI: https://doi.org/10.37547/pedagogics-crjp-02-11-30

ISSN 2767-3278

(C)2021 Master Journals

Crossref do: 81 Google

Accepted 25 $5^{\text {th }}$ November, 2021 \& Published 30 ${ }^{\text {th }}$ November, 2021

qualities, provides young sambists 10-11 years old with a greater increase in speed-power endurance and explosive strength than the training traditionally aimed at the complex development of motor abilities.

A significant improvement in speed-strength abilities, which occurred under the influence of the experimental method, positively influenced the effectiveness of technical and tactical actions of young sambists during the competition.

An increase in the volume of speed-strength exercises in the methodology of training young sambists should be considered as one of the ways to increase the effectiveness of the sports training system of novice athletes. Prospects for further research. Further research deserves the questions of using information technologies for the development of both speed-strength and other physical abilities.

\section{REFERENCES}

1. Maxkamovich, A. Y., \& Abdukahorovich, S. K. (2019). Modern approaches to the content of physical education of schoolchildren in the continuing education system. European Journal of Research and Reflection in Educational Sciences Vol, $7(12)$.

2. Sharipov, H. (2021). The use of outdoor games as a means of developing volitional qualities in preschool children. Society and Innovation, 2 (9 / S), 77-82.

3. Sharipov, Kh. A., \& Pirnazarov, Sh. M. (2020). The value of national and folk games in the upbringing and physical education of children. The Matrix of Scientific Cognition, (5), 352-356.

4. Usmonov, M. K., \& Turdiev, A. G. (2018). Features of the development of the mental process of the boxer. Young Researcher: Challenges and Prospects (pp. 353-357).
5. Usmonov, M. (2019). Role and place of individual lessons in the general boxing training system. International journal of adwanced research, 7(12), 955-958.

6. Turdimurodov, D. (2021). Formation and education of will in schoolchildren in the process of physical education lesson. Mental Enlightenment ScientificMethodological Journal, 2021(02), 64-74.

7. Abdullaev, Ya.M. (2012). Development of physical education of the younger generation in lifelong education. Young Scientist, (11), 381-383.

8. Abdullaev, Y. (2021). Forms and methods of developing the use of folk movement games in high school students. Mental Enlightenment Scientific-Methodological Journal, 2021(2), 73-79.

9. Daminov, I.A. (2021). Sports activity as a factor of influence on the personality of judokas. Academic research in educational sciences, 2 (4), 1322-1329. 